\title{
Issues and concerns on Agriculture productivity and food security in Madhya Pradesh, India.
}

\author{
Dr. Modi Shikha and Dr. Khan T.I. \\ Indira Gandhi Centre for HEEPS, Rajasthan University, India.
}

\begin{abstract}
The glimpses of agriculture in Madhya Pradesh underlines the urgency of state towards addressing the environmentally sustainable agriculture not only for food security but also for social security. Ever since the green revolution was initiated various policies and programmes have been adopted and strategies were made to implement these programmes through various schemes but still agriculture growth could not be linked with GDP growth. The crisis of stagnation in agriculture growth needs urgent attention. The different issues related to policy, institution, technology, socio-economic, accessibility and sustainability if addressed, Madhya Pradesh can attain food security and acheive the Millinium Development Goals.

Keyword: Agriculture, Subsidy, sustainability, Accessibility, food security, WEHAB.
\end{abstract}

\section{Introduction}

The utmost importance of the agriculture can be assessed by this quotation. Sustainable development requires a major contribution from agriculture.

Agriculture is the core competence of Madhya Pradesh.Though agriculture sector provides 80 percent of the employment but its contribution to states GDP is only 35 percent. Thus the poverty in this sector is obvious. The irrigation is critical for Madhya Pradesh, about one third of the state's sown area is currently having irrigation facilities, and the rest $70 \%$ is rainfed and irrigation is substantially below the national average. The Madhya Pradesh is represented by 11 Agro Climatic Zones (ACZs) which makes the state very unique in term of rich agro biodiversity and traditions.

As such there is a blend of constraints and opportunities in this sector which provides a chance to convert all this into strength by making agriculture a reliable source of sustainable development. Although Madhya Pradesh has diversified its cropping systems substantially, there remains scope for intensification and further diversification of agriculture to horticulture and other value crops. The following are the issues and concerns on agriculture productivity and food security in rural Madhya Pradesh :-

\subsection{Policy Issues}

The National Commission on Farmers has rightly pointed out that farmers need a new deal that rebuilds hope about farming. It requires policy makers, particularly at the state level, to make a renewed effort to understand farmer's problems and identify the critical areas of support and reform that will make farmers themselves sufficiently confident about the future of their occupation to put in greater effort and undertake more investment. Since the early 1980s public investment in agriculture has experienced a secular decline, while input subsidies (on fertilizers, power, and canal irrigation) have been rising. As a result the gap between investments and subsidies kept widening. Today input subsidies, together with food subsidies, amount to roughly five to six times the public

Rationed food subsidies are often poorly targeted, and corruption prevents much of the food from reaching the intended beneficiaries. For example, 53 percent of India's rural poor live in three states (Bihar, Uttar Pradesh, and Madhya Pradesh), but their dependence on subsidized food through the PDS off-take is only between 5 and 10 percent of their total cereal consumption-too little to make much difference in their food security. The costs associated with public distribution of food are also often unnecessarily high.

Source: IFPRI, 2005. investment in agriculture. With a burgeoning subsidy bill and shrinking public investment, the growth impetus for agriculture has been declining. Agriculture sector still provides livelihood to nearly 80 percent people of Madhya Pradesh and remains vital for food security. Thus the issues of trade and transition stands more valid for this state.

\section{$>\quad$ Fertilizer subsidy}

One of the proven and well documented reasons for stagnation in the productivity and production growth rate since the early 1990s is the unbalanced use of fertilizers. Although matters have improved considerably since the mid-1990s, the current fertilizer (N:P2O5 : K2O) consumption ratio in the country is 6.5 : 
$2.5: 1$ as against the conventionally accepted ratio of $4: 2: 1$. The consumption ratio in several agriculturally advanced states is still wider.(Survey of Indian Agriculture-2006)

Experimental evidences indicate that the productivity of existing varieties can be enhanced appreciably provided rational crop nutrition schedules are followed. The major bottlenecks are:

- Inadequate availability of straight fertilizers of nutrients other than NPK and zinc;

- Less exposure of extension agencies towards advances in crop nutrition;

- $\quad$ Lack of strong policy support on balanced fertilizer use; and

- $\quad$ Lack of awareness among farmers.

\section{$>\quad$ Water subsidy}

Effective maintenance of the existing system of canal irrigation suffers because the irrigation department of the state lack resources. This in turn is because water charges are kept too low, covering only 20$25 \%$ of the operations and maintenance cost of the system in most states. Poor maintenance leads to loss of water through seepage, with the result that water use efficiency is very low - around 25 to 40 percent instead of 65 percent that should be attainable. Low water charges also encourage highly water intensive crops at the upper end of the canal network, leaving tail-end portions starved of water.

Ground water utilization played a major role in expanding irrigation in the 1980s but uncontrolled exploitation of groundwater has led to serious depletion of the water table in many parts of the country. They are also distributionally unfair because the benefits of under priced water accrue disproportionately to upper end farmers whereas under priced power enables those able to afford larger pumps to lower the water table denying water to farmers who can only afford shallow wells.

\section{Power subsidy}

Continued provision of highly subsidized power by the state is leading to an increase in semi-critical, critical and over exploited areas of groundwater use, which already cover a large number of blocks in the state.

\begin{tabular}{|l|l|l|}
\hline $\begin{array}{l}\text { Power subsidy provided for } \\
\text { Agriculture purpose in MP }\end{array}$ & $\begin{array}{l}\text { Rs. } 1.20 \text { per unit } \\
\text { (up to 14-07-05) }\end{array}$ & $\begin{array}{l}\text { Rs. 0.55 per unit } \\
\text { (from 15-07-05) }\end{array}$ \\
\hline
\end{tabular}

(Survey of Indian Agriculture-2006)

Overexploitation of water is encouraged by the policy of massive under pricing of electricity for agricultural use, with a few states having made electricity for farmers completely free. Even where it is not free, the charge for electricity is a fraction of the average cost, and is not based on metered use. Instead there is a fixed charge for presumed usage, based on the capacity of the pump, an arrangement which implies that the marginal cost of electricity for pumping ground water is zero. Under pricing canal water and electricity are clearly highly distortionary, given the need to conserve water use.

\subsection{Institutional issues}

All over India including Madhya Pradesh Panchayati Raj Institutions (PRIs) have the overall responsibility for social and economic development within their areas of jurisdiction and are responsible for identifying and prioritizing development projects. Fortunately, in Madhya Pradesh PRIs have strong support from the government and functioning as institutions of local self-governance and plan and implement schemes for economic development and social justice. However, a major institutional challenge is that even where service providers exist the quality of delivery is poor and these responsible for delivering the services cannot be held accountable.

The National Commission on Farmers (NCF) has drawn attention to the knowledge deficit that exists at present and explains much of the difference between yields realised in experiments and what farmers actually get. One reason for this is the virtual collapse of extension services in most states, with 30-40\% of positions vacant. Farmers are not fully aware of the adverse consequences of unbalanced fertiliser use or of benefits of micronutrient application and soil testing to determine optimal nutrient requirements is hardly practised on a regular basis even by State Agriculture Departments. Similarly, although many new varieties of seeds and pesticides have entered the market during the last decade and farmers are using these, they do not appear to have significantly higher productivity and there are frequent complaints about quality. A problem is that input dealers, who have narrow commercial interests have emerged as the main vehicle for technology diffusion and farmers do not have access to reliable third-party advice which an effective and knowledgeable extension service should be able to provide. Lack of credit also pushes farmers to purchase inputs from local suppliers who often provide sub-standard inputs.

Krishi Vigyan Kendras set up by Indian Council of Agricultural Research (ICAR), have very little interaction with the Agricultural Technology Management Agency (ATMA) model of extension being promoted by Department of Agriculture \& Cooperation (DAC). The result is that not only are farming practices in large 
parts of the country suboptimal, our plans and programmes are failing to converge technical and development aspects even across Centrally Sponsored Schemes (CSS) of Ministry of Agriculture (MoA), let alone converging effectively with those of other Central Ministries, such as on watershed development.

\subsection{Technological issues}

There is knowledge deficit in agriculture among the farmers in Madhya Pradesh. The inefficient agricultural extension system has resulted in wide gap between research and knowledge implementation. Farmers are not fully aware of the adverse consequences of unbalanced fertilizer use or of benefits of micronutrient application. Soil testing to determine optimal nutrient requirements is hardly practiced on a regular basis by State Agriculture Department. Similarly, although many new varieties of seeds and pesticides have entered the market during the last decade and farmers are using these, they do not appear to have significantly higher productivity and there are frequent complaints about quality. Long term growth depends critically upon technological progress and steps are therefore needed to strengthen agricultural research. Usually farmers adopt new and untried technology, and increase input intensities, they also face larger risks. These risks are often not well understood owing to lack of knowledge of the specific requirements of new seeds and other new technology for achieving productivity gains.

The National Commission on Farmers (NCF) has also drawn attention to the knowledge deficit which constrains agricultural productivity. To overcome this, farmers need effective links to universities and best practices. A good extension system is the means for achieving this linkage but unfortunately the extension system has virtually collapsed in the state, partly as a result of constrains on non-plan expenditure. Krishi Vigyan Kendras set up by Indian Council of Agricultural Research (ICAR), have very little interaction with the Agricultural Technology Management Agency (ATMA) model of extension being promoted by Department of Agriculture \& Cooperation (DAC). Soil testing to determine optimal nutrient requirements is hardly practiced and fertilizer application is often highly unbalanced with excessive use of nitrogenous fertilizers, often leading to a negative effect on productivity of the soil.

\subsection{Socio-economic issues}

In-equality in land distribution and insecurity of tenure etc. are often at the bottom of many forms of social discrimination and domination based on gender, caste, minority and tribal affiliation. Social sector indicators of Madhya pradesh show that while there is progress with time but they are lower than the level achieved by some of the states like Kerala, Tamil Nadu, and Punjab of the country.

The employment situation in this sector presents a serious problem. There is a need to create the opportunities in off-farm and non-farm activities. The income data from the National Accounts shows that the per capita income growth is much less than average amongst the self employed in the unorganized sector and actually negative amongst employees in agriculture.

Horticulture development is currently constrained by poor marketing arrangements. The gap between prices received by the farmers and those paid by urban consumers is large, reflecting inefficient marketing arrangements. Horticultural produce is typically collected from farmers by market agents, who sell it organised markets established under the Agricultural Produce Marketing Acts. Unfortunately these markets are controlled by a few traders and operate on highly non transparent basis. Facilities for grading and handling are poor and methods of price discovery in the markets are nontransparent. Wastage is high owing to poor logistics and the absence of cold chains. The net result is much lower realisation by the farmer.

\subsection{Accessibility}

By and large the delivery of seed, fertilizer, pesticide, existing infrastructure, access to the market and credit are few of the issues which are essential for the growth of agriculture and farmers too. Access to financial resources enable the poor to exploit investment opportunities, reduces their vulnerability to shocks and promote economic growth. Increasing agricultural productivity also depends on the efficient delivery of several other inputs. The quality of seeds and planting material needs to be greatly improved, and this call for strengthening the research effort to make it more effective. The system for producing and marketing certified seeds of existing varieties at reasonable prices also needs to be improved. Seed replacement rates in most parts of the country are only one-third to one-half of what they should be, a situation which reflects partly a lack of knowledge of the importance of seed replacement and partly also a lack of availability of reliable seeds.

But lack of credit at reasonable rates is a persistent problem in large part, reflecting the collapse of the cooperative credit system. The failure of the organized credit system in extending credit has led to excessive dependence on informal sources usually at exorbitant interest rates. This is at the root of former distress reflected in excessive statement. 
Issues and concerns on Agriculture productivity and food security in Madhya Pradesh, India.

\subsection{Sustainability issues}

The survival of the human race depends upon its ability to be in long-lasting equilibrium with nature. However, while the rate of human population growth is declining, the obsolete number of people on earth continues to increase. This places an ever mounting pressure on the earth's limited environmental and natural resource. The use and abuse of these resources determines the sustainability of agriculture. (Atlas of sustainability of food security-2004)

More recently, the mainstreaming of the ecological dimension in the assessment of food security is gaining acceptance by policy makers. Ultimately, we need an evergreen revolution, which implies raising farm productivity in perpetuity without associated ecological or social harm. (Quote: Swaminathan, 1996).

\section{Recomendations for the different issues for agriculture productivity and food security:}

The recommendations are essential to speed up the pace of sustainable development of the state and will help for meeting Madhya Pradesh's obligations under the Millennium Development Goal's. These recommendations will make a positive impact on the well-being of farmer families only if they are given a pronature, pro-poor, pro-women and pro-livelihood orientation.

1. The policy of severely under pricing water from canal systems has two well known adverse effects. It encourages excessive water use, especially in upstream areas, often leading to water logging and salinity, which damages soil productivity. It also weakens the finances of irrigation departments which are unable to maintain existing systems and to complete ongoing projects. Water pricing is a sensitive issue but to leave it unattended for this reason will only perpetuate present problems.

2. An appropriate network of extension service needs to be created to stimulate and encourage both top-down and bottom-up flows of information between farmers, extension workers, and research scientists to promote the generation, adoption, and evaluation of location specific farm technologies.

3. Although a substantial 6 percent of state's GDP is allocated to various rural development programmes, the effectiveness of this expenditure is in some doubts. Agriculture growth can not be revived without rejuvenating support system in extension, credit and the delivery systems of inputs such as seeds, fertilizers, vetenary services

4. The area where Madhya Pradesh lacks behind is the area of livelihood and health care. Madhya Pradesh should strive to enhance its livelihood security and alleviate poverty by augmenting crop yields in a sustainable way, encourage eco-friendly enterprises and non-crop agricultural enterprises

5. Madhya Pradesh is better endowed with natural resources, but currently remains poor. The state will have to pay special attention to poverty alleviation, with intensive and sustainable use of natural resources through eco-friendly and economically viable enterprises.

6. The sustainable use of natural resources requires considerable financial investment both by public and private sector. It also requires other institutional arrangements, peoples participation and adoption of innovative and appropriate technologies. The urgent need is to prevent further depletion and degradation of natural resources which could undermine even present level of sustenance.

7. To achieve total food security, investment in health facilities and basic amenities including safe drinking water are imperative.

8. There is a need to restructure agricultural curriculum and pedagogic methodologies for enabling every farm and home science graduate to become an entrepreneur. The state is far behind in using the biotechnology and Information and Communication technology (ICT) in appropriate manner. These should be used in the production and supply of the inputs needed for sustainable agriculture and development of the process and product for value addition.

9. Subsidies or loans similar to those given to farmers to buy chemical fertilizers / pesticides should be available for organic manures like farm yard manure, compost and biofertilizers and biopesticides also.

10. Fertiliser subsidies need to be comprehensively re-examined to improve balance and also to target the subsidy more to smaller holdings, for example, by limiting the subsidy to a fixed quantity to be given per farmer, with the rest of the market being decontrolled.

\section{Conclusion}

The agriculture is core sector in Madhya Pradesh's economy, social structure and physiography. If the issues are addressed by rationally linking the WEHAB thematic area (Water \& Sanitation, Energy, Health, Agriculture and Biodiversity) through inter-sectoral and multi stakeholders approaches to achieve the targets of development, possibility of sustainable development will increase. This will prove as a tool to find actionoriented practical way to respond to the challenges in the state to better the lives of all human beings, while protecting the environment. 
The issues pertaining to Agriculture and food security are addressed with the analysis of policies / programmes and linkages with other WEHAB thematic areas. The recommendations are essential to speed up the pace of sustainable development of the state and will help for meeting Madhya Pradesh's obligations under the Millennium Development goal's..

\section{References}

[1]. Indian agriculture and rural development: Strategic issues and reform options, IFPRI, 2005.

[2]. Agriculture policy: vision 2020, IARI, New Delhi.

[3]. Promoting sustainable rural development through agriculture, Canadian International development Agency (CIDA),2003.

[4]. Joachim von Braun, M. S. Swaminathan, and Mark W. Rosegrant. Agriculture, Food Security, Nutrition and the Millennium Development Goals. 2002

[5]. Ahluwalia, M.S. 2004-2005. Reducing poverty and hunger in India: The role of agriculture. IFPRI Annual report essay.

[6]. Swati Gola. The patent bill 2005: Impact on agriculture. 2005

[7]. Agriculture and achieving the Millennium Development Goals. IFPRI, 2006.

[8]. Report of the inter-ministry task group on comprehensive medium term strategy for food and nutrition security. Government of India, Planning Commission, April, 2005.

[9]. Agricultural policies in India: Producer support estimate 1985-2002. IFPRI. Feb, 2005

[10]. Perspective on Biodiversity- A vision for mega diverse countries, MOEF, GOI,2006.

[11]. Srijit Mishra. Jan, 2006. Executive summary of Suicide of farmers in Maharashtra. Indira Gandhi Institute of Development Research, Mumbai.

[12]. Towards faster and more inclusive growth: An approach to the $11^{\text {th }}$ five year plan. Government of India, Planning Commission, November, 2006.

[13]. Overview and priority area of action. Government of India, Planning Commission.

[14]. Survey of Indian Agriculture 2006. The Hindu publication.

[15]. Atlas of the sustainability of food security. MSSRF and World Food Programme. 2004.

[16]. Economic Intelligence Service: Agriculture. Centre for Monitoring Indian Economy Pvt Ltd. (CMIE). March, 2006.

[17]. National alliance for mission 2007: Every village a knowledge centre. MSSRF. 2004.

[18]. Fifth Environmental Status Report, EPCO, 2006.

[19]. State Environment Policy, H\&ED, GoMP, 1999.

[20]. Fifth and Final Report, National Commission on Farmers, Government of India Ministry of Agriculture October 2006 